\title{
Role of eosinophils in airway inflammation of chronic obstructive pulmonary disease
}

This article was published in the following Dove Press journal:

International journal of COPD

\author{
Donald P Tashkin' \\ Michael E Wechsler ${ }^{2}$ \\ 'Department of Medicine, David \\ Geffen School of Medicine at UCLA, \\ Los Angeles, CA, USA; ${ }^{2}$ Department \\ of Medicine, National Jewish Health, \\ Denver, CO, USA
}

\begin{abstract}
COPD is a significant cause of morbidity and mortality. In some patients with COPD, eosinophils contribute to inflammation that promotes airway obstruction; approximately a third of stable COPD patients have evidence of eosinophilic inflammation. Although the eosinophil threshold associated with clinical relevance in patients with COPD is currently subject to debate, eosinophil counts hold potential as biomarkers to guide therapy. In particular, eosinophil counts may be useful in assessing which patients may benefit from inhaled corticosteroid therapy, particularly regarding exacerbation prevention. In addition, several therapies targeting eosinophilic inflammation are available or in development, including monoclonal antibodies targeting the IL5 ligand, the IL5 receptor, IL4, and IL13. The goal of this review was to describe the biologic characteristics of eosinophils, their role in COPD during exacerbations and stable disease, and their use as biomarkers to aid treatment decisions. We also propose an algorithm for inhaled corticosteroid use, taking into consideration eosinophil counts and pneumonia history, and emerging eosinophil-targeted therapies in COPD.
\end{abstract}

Keywords: lung disease, pulmonary diseases, corticosteroids, asthma, pneumonia

\section{Introduction}

COPD is a major cause of morbidity and mortality, and is predicted to be the thirdleading cause of death worldwide by $2020 .{ }^{1}$ Health-care costs rise significantly with increased severity of COPD symptoms and exacerbations. ${ }^{1}$ COPD is characterized by persistent, progressive airflow limitation associated with chronic inflammation that is responsible for permanent structural changes to the airway and lungs. These include airway narrowing due to increased wall thickness, mucus occlusion, and destruction of lung parenchyma with loss of lung elasticity. ${ }^{1,2}$

The underlying pattern of inflammation in COPD can vary; most often it is predominated by neutrophils, cytotoxic $\mathrm{CD}^{+} \mathrm{T}$ cells, and alveolar macrophages. ${ }^{2}$ Eosinophils may play a significant role in airway inflammation in some patients with COPD. ${ }^{3}$ While eosinophilic inflammation is most often associated with asthma and has been used to differentiate asthma from COPD, ${ }^{4}$ some studies indicate that approximately a third of patients with COPD have sputum eosinophilia, ${ }^{5-7}$ with prevalence dependent on the eosinophil threshold used and the specific patient population studied. In addition, eosinophil counts in sputum ${ }^{7}$ are increased during exacerbations in some patients with COPD. ${ }^{8}$ Importantly, sputum and/or blood eosinophilia in COPD may predict response to inhaled corticosteroids (ICSs) for prevention of exacerbations ${ }^{7,9}$ and to systemic corticosteroids (CSs) for treatment of exacerbations. ${ }^{10}$

This review describes the biology of eosinophils and their role in COPD airway inflammation during exacerbations and in stable disease, as well as the potential of
Correspondence: Donald P Tashkin David Geffen School of Medicine at UCLA, 10833 Le Conte Avenue, Los Angeles, CA 90095-1690, USA

$\mathrm{Tel}+\mathrm{I} 3108253163$

Fax + I 3I0 2065088

Email dtashkin@mednet.ucla.edu 
eosinophils as biomarkers to inform treatment decisions for COPD patients. An algorithm for the appropriate use of ICS therapy in COPD is proposed, based on the presence of eosinophils and whether or not a history of pneumonia exists, ${ }^{1}$ and the potential role of emerging eosinophil-targeted therapies in COPD is also discussed.

We used a PubMed search from January 1970 through October 2017, with Boolean search terms "eosinophil OR eosinophilia" AND "chronic obstructive pulmonary disease OR asthma". This core search phrase was modified to include "AND biologics", "AND pneumonia", "AND (sputum OR blood)", or "AND corticosteroid". Searches were also conducted on ClinicalTrials.gov for "chronic obstructive pulmonary disease" (or "COPD”), "eosinophil", "biologic" (or "biologic therapy"), or "asthma", "eosinophil", and "biologics" (or "biologic therapy"); the term "phase III" was also used to qualify searches. For web-based searches, terms included "eosinophil", "blood cell”, and "quantification".

\section{Eosinophils: characteristics and methods of quantification}

Eosinophils are key immunoeffector and inflammatory cells. They have diverse functions, with roles in homeostasis and disease in various tissues, including the lungs. ${ }^{11}$ Eosinophils are derived from progenitor stem cells in the bone marrow that are released into the blood upon maturity. ${ }^{12,13}$

Under normal conditions, eosinophils remain quiescent in the blood; upon exposure to proinflammatory mediators (IL3,
IL5, and granulocyte-macrophage colony-stimulating factor; see Figure 1), they may become partially activated before migrating to sites of inflammation. ${ }^{12,14,15}$ IL5 is one of the major cytokines involved in eosinophil-mediated inflammation: it promotes the differentiation, survival, trafficking, activation, and effector functions of eosinophils. ${ }^{13,16}$ Migration of eosinophils to the lungs is controlled by specific chemotactic factors, such as CCL5 (RANTES), CCL7 (MCP3), CCL11 (eotaxin 1), CCL13 (MCP-4), CCL15, CCL24, and CCL26 acting on the CCR3, along with CRTH2, which is expressed on T-helper 2 cells and its ligand, prostaglandin $\mathrm{D}_{2}$ (Figure 1). ${ }^{12,17,18}$ Once in the lungs, proinflammatory mediators, including basic proteins (major basic protein, eosinophil cationic protein, eosinophil peroxidase, and eosinophil-derived neurotoxin), cytokines (IL2, IL3, IL4, IL5, IL10, IL12, IL13, IL16, IL25), chemokines (CCL5, CCL11, CCL13), and growth factors (tumor necrosis factor [TNF], transforming growth factor $[\mathrm{TGF}] \alpha / \beta)$, that are released by eosinophils ${ }^{12,19}$ contribute to sustained inflammation ${ }^{14}$ and tissue damage. ${ }^{14,20}$ In addition, thymic stromal lymphopoietin, an IL7-like proallergic cytokine associated with chronic airway-disease inflammation, ${ }^{21}$ can act on eosinophils to upregulate inflammatory cytokine expression. ${ }^{21,22}$

Blood eosinophil concentration is reported as an absolute count (cells/ $\mu \mathrm{L}$ ) or as a percentage of total leukocytes; studies show that these two quantification methods are concordant. ${ }^{89}$ Eosinophil concentrations in the lungs can also be measured using induced sputum or bronchoalveolar lavage (BAL) fluid,

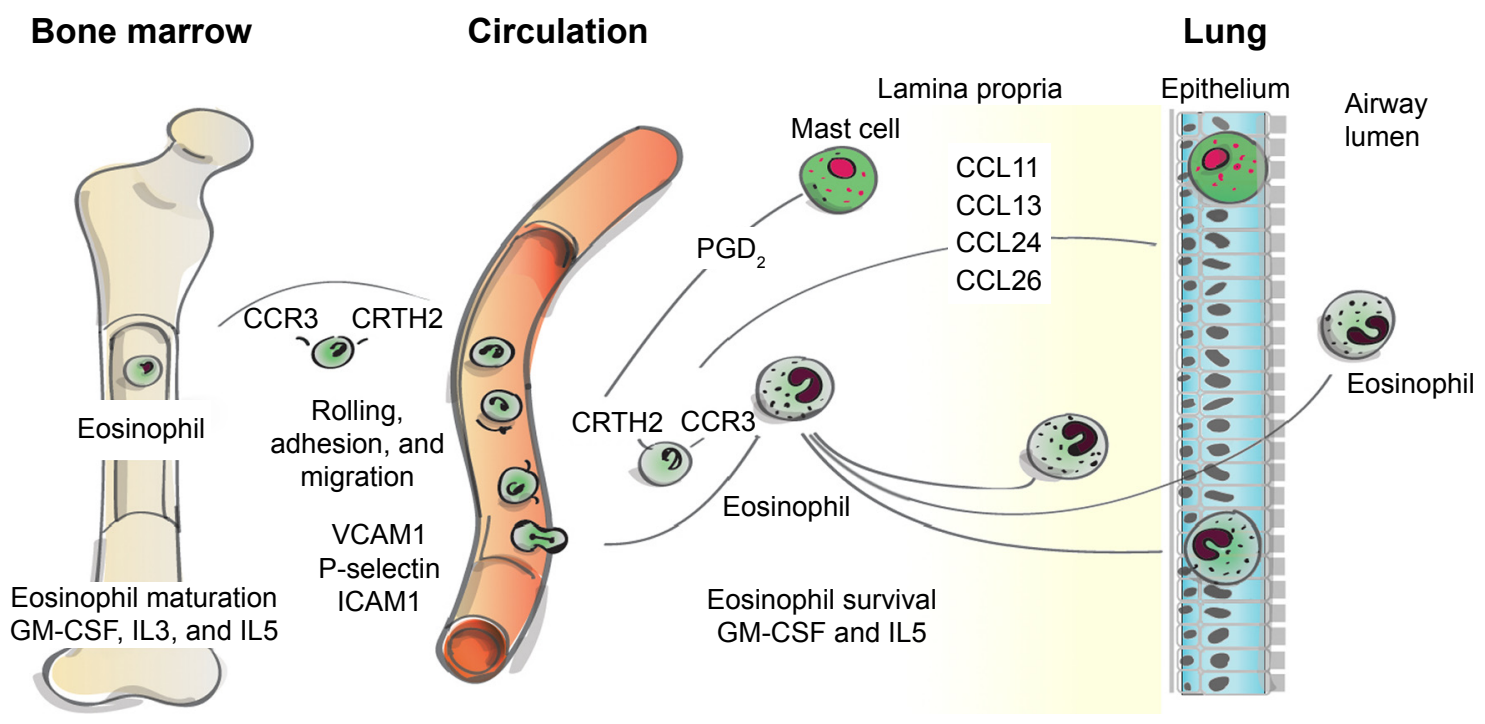

Figure I Eosinophil trafficking from bone marrow to airway.

Notes: Eosinophil activity occurs in tissue. Mature eosinophils leave bone marrow, circulate in blood, and migrate to tissue under the influence of various chemotactic factors. Infiltration into the airways is mediated through adhesion and transmigration across the bronchial vascular epithelium. Chemokines, such as CCL5 and CCLII, and other factors play roles in this process. Reprinted with permission of Sage Publications, Ltd. George L, Brightling CE. Therapeutic Advances in Chronic Disease. 20I6;7(I):34-5I, Copyright 2016. ${ }^{12}$

Abbreviation: GM-CSF, granulocyte-macrophage colony-stimulating factor. 
or by quantifying eosinophils in a biopsy of lung tissue. ${ }^{12}$ Counts are reported as the percentage of eosinophils of total leukocytes in sputum ${ }^{6,23}$ and BAL fluid, ${ }^{24}$ whereas the quantification for eosinophils in biopsy specimens is expressed per specified area of tissue. ${ }^{23,25,26}$ Of note, these eosinophil counts reflect overall levels, and do not consider eosinophil activation.

In the general population, a wide range of eosinophil counts in blood has been reported. ${ }^{27-32}$ Recent studies have reported a median blood eosinophil count of $2.4 \%$ (of total leukocytes) in a general unselected population ${ }^{33}$ and absolute blood eosinophil cell counts of $100-200$ cells/ $\mu \mathrm{L}$ in healthy individuals. ${ }^{34,35}$ In induced sputum, mean percentages of $0.3 \%-1.4 \%$ have been reported for healthy nonsmokers ${ }^{36,37}$; in BAL fluid, the mean proportions of eosinophils are similar in current smokers $(0.2 \%-0.6 \%)$ and former smokers $(0.5 \%)$ and generally lower in healthy never-smokers, with a majority of reports in the range $0.07 \%-0.3 \%$ (but some studies reporting $0.7 \%-0.8 \%$ in this population). ${ }^{36}$ In patients with COPD, median blood eosinophil counts of $2.41 \%-2.70 \% \%^{33,38}$ and $180-230$ cells $/ \mu \mathrm{L},{ }^{33,38,39}$ geometric mean percentages of eosinophils in induced sputum of $0.8 \%-6.2 \%,{ }^{10,40-42}$ and a mean percentage in BAL fluid of approximately $1.0 \%$ have been reported. ${ }^{43}$ In both the general population and patients with COPD, higher eosinophil levels have been found in men versus women. ${ }^{33,44}$

\section{Thresholds for defining high and low eosinophils}

There is a lack of consensus on the appropriate thresholds used to define eosinophilic inflammation in COPD. Because eosinophil numbers differ during stable disease, exacerbations, and following treatment, ${ }^{12}$ the threshold used may depend on the study design and outcomes. In addition, blood eosinophil counts in individuals fluctuate during a 24-hour period. ${ }^{45,46}$ Therefore, it is unlikely that a single threshold will be recommended for guiding all treatment decisions. In sputum, studies have used a threshold of $1 \%,{ }^{47} 2 \%,{ }^{8}$ or $3 \%{ }^{7,10,48}$ for defining eosinophilia in COPD, whereas studies using blood have mostly used a threshold of $2 \%{ }^{9,10,42,49,50}$ However, some of these thresholds (eg, $2 \%$ and $3 \%$ ) were adopted from those established in studies of eosinophilia in asthma, and thus may not necessarily be the optimal threshold for COPD..$^{51,52}$ In a post hoc analysis of the Withdrawal of Inhaled Steroids during Optimized Bronchodilator Management (WISDOM) study, the effect of ICS withdrawal on COPDexacerbation rate was analyzed according to various blood eosinophil thresholds in the ranges of $150-400$ cells $/ \mu \mathrm{L}$ and $2 \%-6 \%$. The most significant deleterious effects of ICS withdrawal on exacerbation risk were observed at thresholds of $\geq 4 \%$ or $\geq 300$ cells $/ \mu \mathrm{L} .{ }^{53}$ Table 1 summarizes recent COPD trials, highlighting eosinophil thresholds used and clinical findings. ${ }^{8,49,53-57}$

\section{Concordance between eosinophil counts in blood and lungs (sputum, BAL, tissue)}

Blood eosinophil concentrations are generally thought to be reasonably good predictors of eosinophil concentrations in the airways. A study of 491 patients with asthma indicated that those with high blood eosinophilia (defined as $\geq 300$ cells $/ \mu \mathrm{L}$ ) had significantly greater mean concentrations of eosinophil counts in induced sputa versus patients with mean blood eosinophil counts $<300$ cells/ $\mu \mathrm{L}(11.7 \%$ vs $0.4 \%$ of leukocytes, respectively; $P<0.001) .{ }^{58}$ Several recent COPD studies have yielded moderate to strong correlations between eosinophil counts in blood and those in sputum, with a positive predictive value (area under the curve [95\% CI]) of 0.85 [0.78-0.93] (during an exacerbation) and 0.76 [0.67-0.84], depending on use of blood eosinophil thresholds of $2 \%$ or $\geq 3 \%$, respectively. ${ }^{10,38}$ Blood eosinophil percentages also correlate with eosinophil counts in bronchial submucosal samples $(r=0.57) .{ }^{59}$ Post hoc analysis from the Evaluation of COPD Longitudinally to Identify Predictive Surrogate End-points (ECLIPSE) study also yielded a positive correlation between blood and sputum eosinophil counts in 138 patients with COPD who had both blood and sputum measurements performed over $\geq 3$ visits. ${ }^{8}$ However, the correlation coefficients $(0.24-0.40)$ were relatively weak. ${ }^{8}$ Hastie et al showed that a blood eosinophil threshold of 250 cells $/ \mu \mathrm{L}$ predicted a sputum eosinophil concentration of $\geq 2 \%$ with a false positive rate of $50 \%$, even with a statistically significant positive correlation between the two values. ${ }^{60}$ In addition, a recent study demonstrated that patients with COPD and high blood eosinophil concentrations ( $>250$ cells $/ \mu \mathrm{L})$ had significantly more eosinophils in sputum, bronchial mucosa, and BAL fluid than those having low blood eosinophil concentrations $(<150$ cells $/ \mu \mathrm{L}) .{ }^{61}$ Moreover, BAL aliquots from patients with high blood eosinophil concentrations, compared to those with low blood eosinophils, exhibited more markers indicative of airway inflammation and remodeling. ${ }^{61}$ These results suggest that blood eosinophil counts may be a simple, albeit somewhat inconsistent, predictor of increased lungresident eosinophils. As blood is easier to obtain than airway samples, blood eosinophil counts may be more readily used in clinical practice. , $^{9,38}$

In contrast to these findings, Turato et al found no correlation between tissue eosinophils assessed in resected lung tissue and blood eosinophils in patients with COPD. ${ }^{62}$ 
Table I Eosinophil thresholds and findings in recent COPD clinical trials

\begin{tabular}{|c|c|c|c|}
\hline Trial & Intervention & Eosinophil thresholds & Clinical findings \\
\hline ECLIPSE $^{8}$ & NA & $\begin{array}{l}\text { Blood } \geq 2 \% \text { of total leukocytes } \\
\text { or } \geq 150 \text { cells/ } / \mathrm{L} \text {; sputum } \geq 2 \% \\
\text { of total leukocytes }\end{array}$ & $\begin{array}{l}\text { Some evidence of clinical benefit in patients } \\
\text { with blood eosinophil counts persistently } \geq 2 \% \\
\text { vs }<2 \% \text { for blood and sputum counts }\end{array}$ \\
\hline TRISTAN ${ }^{49}$ & $\begin{array}{l}\text { Salmeterol } 50 \mu \mathrm{g} \text { BID vs fluticasone } \\
\text { propionate } 500 \mu \mathrm{g} \text { BID, vs salmeterol } 50 \mu \mathrm{g}+ \\
\text { fluticasone propionate } 500 \mu \mathrm{g} \text { BID, vs placebo }\end{array}$ & Blood $\geq 2 \%$ of total leukocytes & $\begin{array}{l}\text { Greater reduction in moderate/severe } \\
\text { exacerbation rates for patients who received } \\
\text { ICS/LABA with } \geq 2 \% \text { eosinophils vs }<2 \%\end{array}$ \\
\hline ISOLDE $^{57}$ & Fluticasone propionate $500 \mu \mathrm{g}$ BID vs placebo & Blood $\geq 2 \%$ of total leukocytes & $\begin{array}{l}\text { Patients with } \geq 2 \% \text { eosinophils had slower rates } \\
\text { of } F E V_{\text {, decline }}\end{array}$ \\
\hline FLAME $^{56}$ & $\begin{array}{l}\text { Indacaterol I I } 0 \mu \mathrm{g}+\text { glycopyrronium } 50 \mu \mathrm{g} \\
\mathrm{QD} \text { vs salmeterol } 50 \mu \mathrm{g} \text { + fluticasone } 500 \mu \mathrm{g} \\
\text { BID }\end{array}$ & Blood $\geq 2 \%$ of total leukocytes & $\begin{array}{l}\text { Effect of indacaterol-glycopyrronium vs } \\
\text { fluticasone-salmeterol on COPD exacerbations } \\
\text { independent of baseline eosinophil count }\end{array}$ \\
\hline WISDOM ${ }^{53}$ & $\begin{array}{l}\text { Tiotropium } 18 \mu \mathrm{g} \text { QD, salmeterol } 50 \mu \mathrm{g} \text { BID } \\
\text { + fluticasone propionate } 500 \mu \mathrm{g} \text { BID for } \\
6 \text { weeks, then patients were randomized to } \\
\text { continued triple therapy or gradual withdrawal } \\
\text { of fluticasone propionate over } 12 \text { weeks }\end{array}$ & $\begin{array}{l}\text { Blood } \geq 2 \%, \geq 4 \%, \geq 5 \%, \text { and } \\
\geq 6 \% \text { of total leukocytes; } \geq 150, \\
\geq 300, \text { and } \geq 400 \text { cells } / \mu \mathrm{L}\end{array}$ & $\begin{array}{l}\text { Baseline blood eosinophil counts of } \geq 4 \% \\
\text { or } 300 \text { cells } / \mu \mathrm{L} \text { correlated with the most } \\
\text { deleterious effect of ICS withdrawal on } \\
\text { moderate or severe exacerbation rates in } \\
\text { patients with severe-very severe COPD }\end{array}$ \\
\hline FORWARD ${ }^{55}$ & $\begin{array}{l}\text { Beclomethasone dipropionate ( } 100 \mu \mathrm{g})- \\
\text { formoterol fumarate }(6 \mu \mathrm{g}) \text { BID vs formoterol } \\
\text { fumarate } 12 \mu \mathrm{g} \text { BID }\end{array}$ & $\begin{array}{l}\text { Blood }<110,<182,<280, \text { and } \\
\geq 280 \text { cells } / \mu \mathrm{L}\end{array}$ & $\begin{array}{l}\text { Pattern of increasing exacerbation frequency at } \\
\text { the highest quartile }(\geq 280 \text { cells } / \mu \mathrm{L}) \text { in patients } \\
\text { treated with formoterol fumurate alone }\end{array}$ \\
\hline NCT0 $227278^{54}$ & $\begin{array}{l}\text { Benralizumab } 100 \mathrm{mg} \mathrm{SC} \text { injection Q4W for } \\
\text { first } 3 \text { doses, then Q8W for next five doses } \\
\text { vs placebo }\end{array}$ & $\begin{array}{l}\text { Blood }<150, \geq 150 \\
<200, \geq 200,<300, \text { and } \\
\geq 300 \text { cells } / \mu \mathrm{L}\end{array}$ & $\begin{array}{l}\text { Numerical but nonsignificant improvements in } \\
\text { acute exacerbations, quality of life, and } F E V_{1} \\
\text { noted in the } \geq 200 \text { and } \geq 300 \text { cells } / \mu \mathrm{L} \text { groups }\end{array}$ \\
\hline $\begin{array}{l}\text { NCTOIO09463 and } \\
\text { NCTOI0I7952 }\end{array}$ & $\begin{array}{l}\text { Fluticasone furoate/vilanterol 50/25, } 100 / 25 \text {, } \\
\text { or } 200 / 25 \mu \mathrm{g}(\mathrm{QD}) \text { or vilanterol } 25 \mu \mathrm{g} \text { alone } \\
\text { (QD) }\end{array}$ & Blood $2.4 \%$ of total leukocytes & $\begin{array}{l}\text { Linear relationship between eosinophil } \\
\text { concentrations and treatment outcomes. } \\
\text { Cluster-analysis algorithm separated the } \\
\text { clusters close to the median percentage of } \\
\text { blood eosinophils }(2.6 \%)\end{array}$ \\
\hline
\end{tabular}

Abbreviations: BID, bis in die (twice daily); FEV ${ }_{1}$, forced expiratory volume in I second; ICS, inhaled corticosteroid; LABA, long-acting $\beta$-agonist; NA, not available; Q4W, every 4 weeks; Q8W, every 8 weeks; QD, quaque die (once daily); SC, subcutaneous.

Interestingly, the authors also reported that low eosinophils were, if anything, associated with worse outcomes in COPD patients than high eosinophils, possibly due to a beneficial effect of eosinophils on host defense (eosinophils have been shown to contribute to the immune response against infection via their antimicrobial function) ${ }^{63}$

The prevalence of eosinophilia in COPD patients varies depending on the threshold used for evaluation. In a meta-analysis of ten trials, $63 \%$ of patients $(n=10,861)$ had blood eosinophil counts $\geq 2 \% .{ }^{50}$ In the WISDOM trial, $53 \%$ of patients had $\geq 150$ eosinophils $/ \mu \mathrm{L}, 20 \%$ had $\geq 300$ eosinophils $/ \mu \mathrm{L}$, and $11 \%$ had $\geq 400$ eosinophils $/ \mu \mathrm{L}$ (total number of patients with eosinophil-count data 2,420). ${ }^{53}$ In a population-based matched-cohort study, $34.9 \%$ of 39,824 COPD patients had blood eosinophil counts of $\geq 340$ cells $/ \mu \mathrm{L}$ compared with $25.8 \%$ of matched non-COPD controls ( $\mathrm{n}=90,772, P<0.001) ; 36.4 \%$ of the COPD patients in this study had blood eosinophil counts of $<2 \%$, whereas $38.3 \%$, $16.3 \%$, and $9.2 \%$ had elevated blood eosinophil counts based on thresholds of $2.0 \%-3.9 \%, 4.0 \%-5.9 \%$, and $\geq 6.0 \%$, respectively. ${ }^{64}$

\section{Persistence of eosinophilia in COPD}

The detection of elevated eosinophil concentrations and eosinophil-associated proinflammatory factors in the airways and blood of patients with $\mathrm{COPD}^{65-67}$ suggests that eosinophils actively contribute to inflammatory processes in these patients. However, evidence suggests that eosinophilic inflammation may not persist over time. A post hoc analysis of the ECLIPSE study found that $37.4 \%$ of patients with COPD had persistently elevated blood eosinophil counts ( $\geq 2 \%$ at baseline and years 1,2 , and 3 ), whereas $49 \%$ had intermittent elevation of eosinophils. ${ }^{8}$ In that analysis, the group with persistently elevated blood eosinophils was slightly older, had a higher proportion of males, and had a smaller percentage of current smokers compared with the other groups. ${ }^{8}$

In an 8-year follow-up of patients with COPD and matched non-COPD controls, the percentage of patients with COPD and persistently high eosinophil counts ( $\geq 340$ cells $/ \mu \mathrm{L}$ ) was $80 \%$ at 6 months and $30 \%$ at 4 years, declining to $18 \%$ at 8 years. ${ }^{64}$ Over the entire follow-up period, the stability of eosinophil counts was significantly lower in patients with 
COPD versus controls and in patients with COPD with higher versus lower eosinophil counts $(\geq 340$ vs $<340$ cells $/ \mu \mathrm{L}$, respectively). The authors suggested that the decreased eosinophil-count stability seen in patients with COPD may be related to variations in disease stability (eg, exacerbations) or pharmacologic therapy (eg, oral CS courses) that would not be seen in the non-COPD controls. ${ }^{64}$

A secondary analysis of the Acute Exacerbation and Respiratory InfectionS in COPD (AERIS) cohort examined the stability of eosinophilic inflammation in COPD, and found that blood eosinophil counts $\geq 2 \%$ were stable ( $\leq 1$ visit with count $<2 \%$ allowed) over a year in $58 \%$ of patients and predicted an overall lower risk of bacterial presence at exacerbation. ${ }^{68}$ Furthermore, the subset of patients who underwent bronchoscopy in the Subpopulations And Intermediate Outcomes in COPD Study (SPIROMICS; NCT01969344) ${ }^{69}$ showed significantly increased BAL eosinophils for current smokers with COPD compared with former smokers with and without COPD, as well as current smokers without COPD. ${ }^{70}$ Other large observational studies - Genetic Epidemiology of COPD (COPDGene; NCT00608764) ${ }^{71}$ and The Novel Observational Longitudinal Study (NOVELTY; NCT02760329) ${ }^{72}$ - that are currently under way will further characterize patients with COPD and healthy volunteers and provide more insight into the eosinophil profiles of these populations.

\section{Eosinophilic inflammation in COPD Relationship to exacerbations of COPD}

A growing body of evidence supports an association between high eosinophil concentrations and exacerbations of COPD. ${ }^{3,10,33,55,73}$ Some studies have noted greater eosinophil counts during exacerbations compared with periods of stable disease, ${ }^{3}$ while others have reported an association between greater eosinophil counts and an increased exacerbation risk. ${ }^{33,55,73}$ In a 1-year observational study in which 86 patients had 182 COPD exacerbations, four distinct clusters of exacerbation type were identified: bacterial, viral, eosinophilic, and pauci-inflammatory. ${ }^{10}$ Overall, 55\% of exacerbations were bacteria-associated, 29\% were virus-associated, and $28 \%$ were associated with sputum eosinophilia (descriptions were not mutually exclusive; the pauci-inflammatory cluster was defined by limited changes in inflammatory profile). The inflammatory profile associated with the eosinophilic cluster in this study included sputum CCL17, CCL13, and IL5 and serum CCL17, CXCL11, and IL5. ${ }^{10}$ As noted earlier, eosinophils migrate to the lungs under the influence of cytokines (IL5 in particular) and specific chemotactic factors (such as eotaxin 1 and RANTES), along with CRTH2 and prostaglan$\operatorname{din} \mathrm{D}_{2}{ }^{12,17,18}$ (Figure 1). Once in the lungs, eosinophil-derived, proinflammatory mediators, including basic proteins, cytokines, and growth factors, promote persistent inflammation, ${ }^{12,14}$ which contributes to exacerbations. Viral and/or bacterial infections are found in a majority of exacerbations. ${ }^{74}$

Eosinophil counts vary between stable and exacerbated COPD states. In a study by Fujimoto et al, sputa from healthy nonsmokers, patients with stable COPD (no exacerbation during the 2- to 3-year study period), and patients with unstable COPD ( $\geq 1$ exacerbations during the study) were examined. Among unstable COPD patients, sputa were examined during stable (defined as stable condition for $\geq 3$ months with normal day-to-day variations and without signs of airway infection) and exacerbation phases. ${ }^{75}$ Significant increases in eosinophil concentrations were found in both stable- and unstable-COPD cohorts compared with healthy nonsmokers. Greater concentrations of eosinophil chemotactic factors were found in sputa from patients with unstable COPD during an exacerbation compared with a stable phase and compared with patients with stable COPD and healthy nonsmokers. ${ }^{75}$ In another study of patients who had an acute COPD exacerbation, those with eosinophilia ( $\geq 2 \%$ or $\geq 300$ cells $/ \mu \mathrm{L}$ ) had a significantly shorter length of stay (5 days) and reduced early treatment failure rate $(10.3 \%)$ compared with patients who did not have elevated eosinophils ( 7 days and $27.4 \%$, respectively); however, relapse was significantly more frequent in the eosinophilic group ( $72 \%$ vs $42.2 \%$ ). ${ }^{76}$

Evaluation of ICS efficacy for treating exacerbations in COPD patients with elevated eosinophil counts supports an association between eosinophils and exacerbations, although results between studies are conflicting. Cheng et al found in a post hoc analysis of 248 patients with COPD treated with medium-or high-dose ICS in combination with a LABA. that a higher percentage of patients with baseline (prerandomization) blood eosinophil counts $\geq 3 \%$ had a history of acute exacerbations with $\geq 1$ hospitalizations in the prior year (before study start) compared with patient baseline blood eosinophil counts $<3 \%$ (27.1\% vs $7.4 \%$, respectively) ${ }^{77}$ In a study of 82 patients with COPD, Siva et al found that treating patients both to minimize eosinophilic airway inflammation based on induced sputum eosinophil count (ie, adjusting ICS therapy based on predetermined eosinophil thresholds) and optimize symptom control was associated with a greater reduction in severe exacerbations compared with treating patients only to minimize symptoms ${ }^{78}$ (Figure 2). Conversely, Barnes et al found in the Inhaled Steroids in Obstructive 


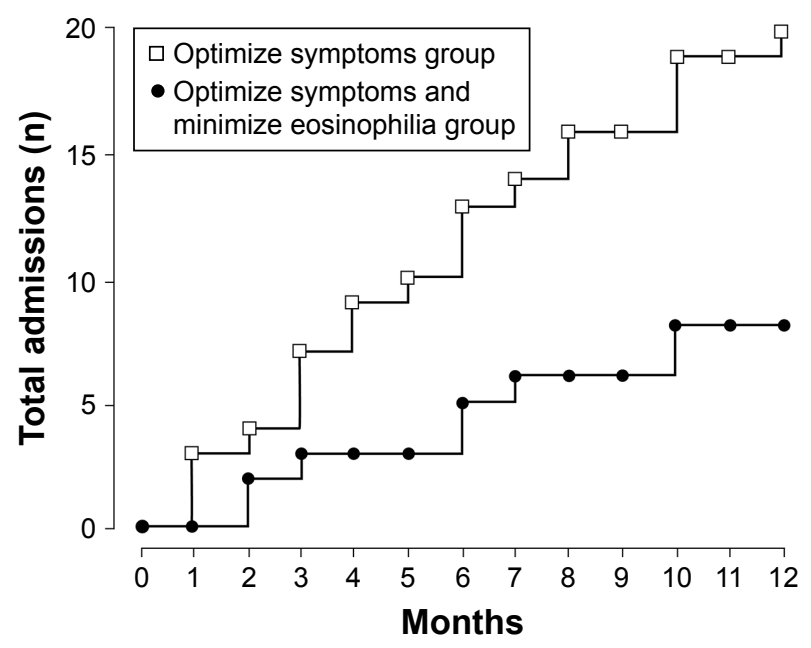

Figure 2 Hospital admissions due to exacerbations in COPD patients treated to optimize symptoms alone or in combination with minimizing eosinophil counts.

Notes: Patients treated to optimize symptoms only $(\square ; n=I I)$; and those treated to optimize symptoms and minimize airway eosinophil inflammation (minimize eosinophilia, keeping sputum eosinophil at $<3 \%)(\bullet ; n=12)$. For patients in the optimize symptoms only group, the hierarchy of treatment was short-acting $\beta_{2}$ agonist, regular anticholinergic, LABA, LAMA, theophylline, and then a trial with a nebulizer; inhaled corticosteroids continued at the same dosage if the patient was already receiving them. For patients in the optimize symptoms and minimize sputum eosinophils group, treatment hierarchy was the same as above. However, patients received the smallest appropriate dosage of anti-inflammatory treatment (ICS or oral CS) to keep sputum eosinophil counts $<3 \%$; if eosinophil counts were $>3 \%$, then anti-inflammatory treatment was increased. Reproduced with permission of the European Respiratory Society from Siva R, Green RH, Brightling CE, et al. Eosinophilic airway inflammation and exacerbations of COPD: a randomised controlled trial. Eur Respir J. 2007;29(5):906-913.78 [Disclaimer: This material has not been reviewed prior to release; therefore, the European Respiratory Society may not be responsible for any errors, omissions, or inaccuracies, or for any consequences arising there from, in the content.]

Abbreviations: CS, corticosteroid; ICS, inhaled corticosteroid; LABA, long-acting $\beta$-agonist; LAMA, long-acting muscarinic antagonist.

Lung Disease in Europe (ISOLDE) study of patients with moderate to severe COPD who received ICS treatment, that the percent reduction in the overall exacerbation rate for fluticasone propionate versus placebo was higher in patients with blood eosinophil levels $<2 \%$ versus $\geq 2 \%$. ${ }^{57}$ The difference between the results of these two studies might be attributable to differing methodologies: the Siva et al study ${ }^{78}$ optimized anti-inflammatory treatment based on the level of sputum eosinophils, whereas a fixed dose of ICS plus as-needed short-acting bronchodilator therapy was used in the study reported by Barnes et al. ${ }^{57}$ Kolsum et al recently demonstrated clear differences in markers for airway inflammation in 20 COPD patients with high blood eosinophil concentrations $(>250$ cells $/ \mu \mathrm{L})$ compared with 21 patients with blood eosinophil concentrations of $<150$ cells $/ \mu L$. Although the study involved a small number of patients $(n=41)$, it provides insight into how inflammatory processes in the lung, driven in part by eosinophils, could result in differential response in patients to ICS therapy. ${ }^{61}$

\section{Relationship to pneumonia}

A few studies have examined the effect of blood eosinophil count on the incidence of pneumonia in patients with COPD. ${ }^{50,77}$ Cheng and Lin found that patients with COPD and high eosinophil levels ( $\geq 3 \%$ ) responded to ICS/LABA therapy better (greater improvement in percentage-predicted forced expiratory volume in 1 second $\left(\mathrm{FEV}_{1}\right)$, quality of life, frequency of annual exacerbations) than those with concentrations $<3 \%$; however, no difference in pneumonia incidence in response to ICS/LABA treatment was observed based on high and low eosinophil concentrations. ${ }^{77}$ Results from a much larger retrospective study showed that patients with COPD had slightly fewer episodes of pneumonia if they had a blood eosinophil count of $\geq 2 \%$ versus $<2 \%$, regardless of whether their medication regimen included an ICS. ${ }^{50}$ The authors speculated that patients with eosinophil counts $\geq 2 \%$ may have better capacity for clearing the lungs of infections before progressing to pneumonia than patients with $<2 \%$ eosinophil levels, due to the antimicrobial defense role of eosinophils. Consistent with this proposal, an inverse relationship between bacterial infection and blood eosinophil counts has been observed in patients with COPD in an exacerbated state. This further suggests that the ICS responsiveness observed with higher eosinophil counts may be affected by bacterial levels, with lower levels of infection associated with ICS responsiveness. ${ }^{79}$ Indeed, in a recent clinical study, an increase in bacterial load was observed in patients with stable, moderate COPD who received LABA/ICS therapy and had low blood or sputum eosinophils $(\leq 2 \%)$ at baseline. Increases were not observed in LABA + ICS-treated patients with higher eosinophil levels at baseline or those treated with LABA alone, regardless of eosinophil level at baseline. ${ }^{80}$

\section{Relationship to lung function}

The exact nature of the relationship between eosinophilic inflammation and decrements or rates of decline in lung function in patients with COPD remains unclear. ${ }^{3}$ In a small sample of patients with moderate-severe COPD $(n=10)$, lower $\mathrm{FEV}_{1}$ values were associated with greater sputum concentrations of both eosinophils and eosinophil cationic protein (a biomarker of eosinophilic inflammation), potentially suggesting a link between airway eosinophilia and airflow obstruction. ${ }^{66}$ Similarly, in comparison with asymptomatic smokers, COPD and chronic bronchitis, defined by an $\mathrm{FEV}_{1}<80 \%$ (predicted) in addition to symptoms of chronic bronchitis, has been associated with an increased ratio of activated eosinophils to total eosinophils infiltrating largeairway subepithelia. ${ }^{81}$ In COPD patients with emphysema 
$(n=16)$ versus current smokers without emphysema $(n=8)$, significantly higher levels of eosinophil markers (eosinophil cationic protein and eotaxin 1) were observed in BAL fluid. ${ }^{82}$ In a subgroup analysis of the Feasibility of Retinoids for the Treatment of Emphysema (FORTE) study in patients with COPD with emphysema $(n=27)$, high eotaxin 1 concentrations in BAL fluid $(>50 \mathrm{pg} / \mathrm{mL})$ and plasma $(>1,300 \mathrm{pg} / \mathrm{mL})$ were predictive of a rapid decline in lung function over 6 months ( $\geq 10 \%$ decrease in percentage-predicted $\left.\mathrm{FEV}_{1}\right){ }^{83}$ In the COPD cohort $(n=7,225)$ of the Copenhagen General Population Study, individuals with elevated blood eosinophil counts $(\geq 340$ cells $/ \mu \mathrm{L}$ [threshold associated with an increased risk of exacerbations]) had slightly lower percentage-predicted $\mathrm{FEV}_{1}$ values than individuals with lower eosinophil counts. ${ }^{33}$ The elevated blood eosinophil subgroup included a greater percentage of men, heavier smoking history, greater likelihood of experiencing wheezing during a cold, and greater probability of producing sputum for at least 3 months. ${ }^{33}$ In contrast, in the ECLIPSE study $(n=1,483)$, a subset of patients with blood eosinophil concentrations persistently $\geq 2 \%(n=554)$ had a higher mean $F^{2} V_{1}$ percentage predicted than patients with blood eosinophil concentrations persistently $<2 \%$ ( $\mathrm{n}=201,51 \%$ vs $48 \% ; P=0.009)$. They also tended to be slightly older and male. ${ }^{8}$

ICS treatment may have a differential impact on lung function in patients with COPD, depending on whether eosinophil concentrations are normal or elevated. A post hoc analysis from the ISOLDE trial, evaluating fluticasone propionate versus placebo in 751 patients with moderate-severe COPD, reported that ICS-treated patients with elevated blood eosinophils ( $\geq 2 \%$ ), but not those with blood eosinophils $<2 \%$, experienced a significantly lower rate of decline in $\mathrm{FEV}_{1}$ versus patients treated with placebo $(P=0.003) .{ }^{57}$ These results suggest that lung function in patients with high eosinophil levels is more responsive to ICS therapy.

\section{ICS-treatment considerations in COPD \\ Role of eosinophils and pneumonia history}

The current thinking on the role of ICS in COPD therapy has evolved, in part because of evidence suggesting an increased risk of pneumonia with ICS treatment in some patients, ${ }^{84-89}$ in addition to evidence of superior efficacy of a LABA-longacting muscarinic antagonist (LAMA) combination compared to LABA-ICS in reducing exacerbations. ${ }^{56}$ The Global Initiative for Chronic Obstructive Lung Disease (GOLD) 2017 strategy recommends use of ICS in combination with a
LABA in patients with COPD with exacerbations who have a history of asthma or findings suggestive of asthma-COPD overlap (ACO), or in combination with a LAMA and a LABA in those with further exacerbations despite treatment with dual long acting-bronchodilator therapy. ${ }^{1}$ High eosinophil counts may also support use of ICS (in combination with bronchodilator therapy) in COPD; however, the GOLD statement notes the relationship is still under debate, and no specific recommendations for thresholds indicating eosinophilia are provided. ${ }^{1}$

\section{Impact of eosinophils on responses to ICS therapy}

Across several studies, elevated eosinophil concentrations have been found to predict response to ICS in patients with COPD. ${ }^{9,55,57,90}$ In patients with blood eosinophil counts of $\geq 2 \%$, ICS-LABA has significantly reduced exacerbation rates compared with placebo $(P<0.001$; Trial of Inhaled Steroids And Long-Acting $\beta_{2}$ Agonists [TRISTAN] study) and with tiotropium $(P=0.006$; Investigating New Standards For Prophylaxis in Reducing Exacerbations [INSPIRE] study). ${ }^{49,52}$ In contrast, there were no significant differences in exacerbation rates between treatments in patients with blood eosinophil counts $<2 \%$ in either study. ${ }^{49}$ In addition, a post hoc analysis of the WISDOM trial showed that patients with high blood eosinophil counts tended to be more sensitive to withdrawal of ICS from a LABA-LAMA-ICS combination and had an increase in exacerbations when ICS therapy was stopped ${ }^{53}$ Exacerbation-rate differences between patients who were maintained on ICS therapy and those who stopped ICS therapy increased with increasing blood eosinophil thresholds; a significant treatment-by-subgroup interaction was seen at the $4 \%$ and $5 \%$ and 300 and 400 cells $/ \mu \mathrm{L}$ thresholds only. The authors suggested that a threshold of $\geq 4 \%$ or $\geq 300$ cells $/ \mu \mathrm{L}$ may identify patients in whom ICS withdrawal from a triple combination may be detrimental. ${ }^{53}$

In contrast, the Effect of Indacaterol Glycopyrronium vs Fluticasone Salmeterol on COPD Exacerbations (FLAME) study found no association between baseline eosinophil concentration and response to ICS treatment. ${ }^{56}$ In this study, the annual rate of exacerbations was lower with indacaterolglycopyrronium (LABA-LAMA) versus salmeterolfluticasone (LABA-ICS), independently of baseline blood eosinophil concentration ( $<2 \%$ vs $\geq 2 \%$ ). ${ }^{56}$ Subsequent analyses of this study did not indicate a significant difference in the rate of exacerbations between the LABA-LAMA and LABA-ICS groups at higher baseline eosinophil thresholds (ie, $\geq 3 \%, \geq 5 \%$, or $\geq 300$ cells $/ \mu \mathrm{L}$ ). ${ }^{91}$ It would be of interest 
to investigate differences in treatment regimens based on high eosinophil levels in patients with a frequent-exacerbator phenotype (ie, $\geq 2$ moderate or severe exacerbations or $\geq 1$ severe [ie, hospitalized] exacerbations in the previous year). Because data analysis by eosinophil threshold in the FLAME study was presented for all exacerbations or combined moderate and severe exacerbations, it would be interesting to examine the results for moderate and for severe exacerbations separately. In that regard, the Copenhagen General Population study reported a significantly greater risk of severe exacerbations, but not of moderate exacerbations, in patients with COPD and a blood eosinophil count of $\geq 3.3 \%$ versus $<3.3 \%{ }^{33}$

\section{Patients with $\mathrm{ACO}$}

Patients with COPD who also have clinical features associated with asthma have been described as having ACO. The overlap in clinical features varies, with some patients having more asthma symptoms, including evidence of $\mathrm{T}_{\mathrm{H}} 2$-mediated inflammation and increased eosinophils and/or mast cells, whereas others have more COPD symptoms and neutrophilic inflammation. ${ }^{92-94}$ ACO remains a controversial topic, and some experts consider it an oversimplification, with the entity more likely to comprise a spectrum of diseases and phenotypes than a single disorder. ${ }^{95}$

At present, there is no clear definition of ACO. The 2017 Global Initiative for Asthma (GINA) strategy report described ACO as

characterized by persistent airflow limitation with several

features usually associated with asthma and several features usually associated with COPD. ${ }^{96}$

Diagnosis requires similar numbers of these features in asthma and COPD ( $\geq 3$ for each). Although the presence of elevated eosinophils in sputum is noted as a usual feature of ACO, no consistent recommendations on thresholds are provided. ${ }^{97-99}$ In line with this, individual clinical studies may include eosinophil thresholds as part of the definition of ACO, but not as a requirement for the condition. ${ }^{100}$ However, thresholds for high sputum eosinophils, including both $\geq 2 \%{ }^{24,51}$ and $\geq 3 \%,{ }^{7,10,48,100}$ have been proposed as clinically relevant in patients with COPD. The latter threshold, $\geq 3 \%$ sputum eosinophil level, is consistent with that proposed for the Czech diagnostic criteria for ACO. ${ }^{98}$ To our knowledge, no published studies have specifically evaluated the relationship between eosinophil thresholds and treatment response to ICS in patients with ACO. Based on recommendations by GINA, however, the therapy for patients identified as having ACO is first to treat for asthma, including use of ICS, until further evaluations are undertaken. ${ }^{96}$

The most current update (2017) to the Spanish COPD guidelines include specific criteria for identification of ACO.${ }^{101}$ To establish a diagnosis, a patient should fulfill the criteria for COPD (35 years of age or older, a smoking history, and a postbronchodilator $\mathrm{FEV}_{1} /$ forced vital capacity $<70 \%$ ) and have an asthma diagnosis. In cases in which a diagnosis of asthma cannot be established, a marked response to a bronchodilator $\left(\mathrm{FEV}_{1} \geq 15 \%\right.$ and $\geq 400 \mathrm{~mL}$ ) or an elevated blood eosinophil count of $\geq 300$ cells $/ \mu \mathrm{L}$ is diagnostic of ACO. ${ }^{101}$ The most recent Czech Republic COPD guidelines ${ }^{98}$ and guidelines recently proposed by Cosío et $\mathrm{al}^{99}$ also include specific diagnostic criteria for ACO similar to those in the Spanish guidelines, albeit with the inclusion of a recommended sputum eosinophil threshold concentration $\geq 3 \%{ }^{98}$ and blood eosinophil threshold concentrations $>5 \%{ }^{99}$ in the Czech Republic and Cosío et al guidelines, respectively. Similarly to the 2017 Spanish guidelines, a recently proposed consensus definition included an eosinophil concentration $\geq 300$ cells $/ \mu \mathrm{L}$ as one possible minor criterion that can be used with major criteria (based on lung function, smoking history, or a history of asthma) to identify ACO. ${ }^{95}$

\section{Assessing risk with ICS: focus on pneumonia}

ICS use is associated with certain risks that should be taken into account when assessing the benefit:risk ratio of ICS therapy. In particular, studies have reported that patients with COPD receiving ICS are at increased risk of developing pneumonia. ${ }^{84-89,102}$ In addition, potential differences in risk for pneumonia may be affected by the specific ICS used. ${ }^{86,103,104}$ Therefore, considering a patient's prior history of pneumonia may be important when choosing ICS therapy as part of the COPD-treatment regimen.

Notably, the 2017 GOLD statement bases COPD treatment recommendations predominantly on the basis of burden of respiratory symptoms and history of exacerbations, while neither pneumonia history nor the presence of eosinophilia is factored into the COPD-treatment algorithm. ${ }^{1}$ Therefore, we propose a new algorithm for optimizing treatment of COPD patients that takes these factors into consideration (Table 2). For COPD patients with high eosinophil counts and no history of pneumonia, ICS is recommended as part of therapy, as treatment benefits (improved lung function and reduced symptoms and rate of exacerbations) ${ }^{1}$ are high and risk of pneumonia comparatively low. Whether or not ICS treatment should be recommended in patients with 
Table 2 Consideration for inclusion/exclusion of ICS as part of therapy

\begin{tabular}{|l|l|l|}
\hline & $\begin{array}{l}\text { High eosinophil } \\
\text { counts }\end{array}$ & $\begin{array}{l}\text { Low eosinophil } \\
\text { counts }\end{array}$ \\
\hline $\begin{array}{l}\text { History of } \\
\text { pneumonia? }\end{array}$ & $\begin{array}{l}\text { No history of } \\
\text { pneumonia } \\
\text { High benefit and } \\
\text { low risk }\end{array}$ & $\begin{array}{l}\text { History of pneumonia } \\
\text { uncertain } \\
\text { No data available to support } \\
\text { benefit over risk of using ICS }\end{array}$ \\
\cline { 2 - 3 } & $\begin{array}{l}\text { History of pneumonia } \\
\text { uncertain } \\
\text { Need to weigh benefit/ } \\
\text { risk of individual patient }\end{array}$ & $\begin{array}{l}\text { History of pneumonia } \\
\text { High risk with low benefit }\end{array}$ \\
\hline
\end{tabular}

Notes: Patients with COPD with exacerbations ( $\geq 2$ or $\geq 1$ exacerbations leading to hospitalization) based on high/low eosinophils and no history/history of pneumonia. Thresholds for high and low eosinophil counts continue to be explored; currently, there is no agreement on these thresholds. Please refer to the text for discussion. Abbreviation: ICS, inhaled corticosteroid.

COPD with low eosinophil counts with or without a history of pneumonia is still not clear. In the situation of a patient with high eosinophil counts plus a history of pneumonia, the benefits and risks must be evaluated on a case-by-case basis. For example, an ICS may be considered in patients with high eosinophil counts and a history of pneumonia who continue to have exacerbations, particularly those leading to hospitalization, while on dual-bronchodilator therapy, assuming the benefit of decreasing future exacerbations outweighs the potential risks.

\section{Emerging treatments for COPD with eosinophilic inflammation}

Several therapeutics targeting eosinophils are in development (Table 3). ${ }^{54,105-113}$ As previously discussed, IL5 is the principal eosinophilic regulatory cytokine that promotes the differentiation, survival, and activation of eosinophils..$^{13,16}$ Treatments successfully targeting the IL5 pathway to reduce eosinophilic inflammation in asthma are now under investigation in COPD.

Mepolizumab is a humanized monoclonal antibody that targets the IL5 ligand and inhibits IL5-receptor signaling in eosinophils. Mepolizumab was approved by the US Food and Drug Administration (FDA) in 2015 as adjunct treatment in patients with severe asthma and eosinophilic inflammation. ${ }^{114,115}$ Clinical benefits of mepolizumab in patients with eosinophilic asthma include reductions in exacerbation rate and asthma symptoms, ${ }^{116-118}$ improvement in $\mathrm{FEV}_{1},{ }^{117}$ and reduced oral CS use. ${ }^{116}$ Although an initial pilot study ${ }^{119}$ did not show significant improvement with mepolizumab in lung function or reductions in exacerbations in patients with COPD, results from two Phase III studies showed some improvements in exacerbation frequency in mepolizumab-treated patients who had an eosinophilic phenotype (Table 3) ${ }^{105,106,113}$ In both of these Phase III studies, patients had COPD and had experienced moderate or severe exacerbations while using inhaled glucocorticoid-based triple therapy. The primary end point for both studies was the annual rate of exacerbations considered moderate (defined as leading to use of systemic glucocorticoids and/or antibiotics) or severe (defined as leading to hospitalization or death). In METREX, ${ }^{113}$ patients were divided into an eosinophilic group ( $\geq 150$ cells $/ \mu \mathrm{L}$ at screening or $\geq 300$ cells $/ \mu \mathrm{L}$ anytime during the prior year) and a noneosinophilic group. Among patients with an eosinophilic phenotype, those treated with mepolizumab $100 \mathrm{mg}$ had a significantly lower annual moderate/severe exacerbation rate compared with placebo-treated patients ( 1.40 vs 1.71 ; adjusted $P=0.04$ ); no treatment difference was observed in the total population. In METREO, ${ }^{113}$ all patients were required to have an eosinophilic phenotype (as defined in METREX). Despite this, the annual moderate/severe exacerbation rate was not significantly different for the mepolizumab $100 \mathrm{mg}$, mepolizumab $300 \mathrm{mg}$, and placebo-treatment groups $(1.19,1.27$, and 1.49, respectively). Together, results from the METREX and METREO studies indicate a role for eosinophils in COPD, but suggest that more study is needed to understand the mechanisms underlying COPD.

Reslizumab is a humanized anti-IL5 monoclonal antibody that was approved by the FDA in 2016 as an add-on maintenance treatment in adult patients with severe asthma and an eosinophilic phenotype. ${ }^{120}$ Similarly to mepolizumab, it targets the IL5 ligand. ${ }^{121}$ Two 52-week Phase III studies showed that reslizumab significantly reduced asthma exacerbations and increased $\mathrm{FEV}_{1}$ in patients with eosinophilic asthma ( $\geq 400$ cells $/ \mu \mathrm{L}$ ). ${ }^{122}$ Reslizumab has yet to be formally evaluated in clinical trials for COPD treatment.

Benralizumab is a humanized, afucosylated, monoclonal antibody targeting the IL5-receptor $\alpha$-chain. ${ }^{123}$ Benralizumab depletes eosinophils through antibody-dependent, cell-mediated cytotoxicity via apoptosis of eosinophils induced by activated natural-killer cells. In Phase III clinical studies in severe eosinophilic asthma (blood eosinophil counts of $\geq 300$ cells $/ \mu \mathrm{L}^{123,124}$ or $\geq 150$ to $<300$ cells $/ \mu \mathrm{L}^{125}$ ), benralizumab significantly reduced the annual rate of exacerbations, ${ }^{123}$ increased $\mathrm{FEV}_{1},{ }^{123,124}$ reduced asthma symptoms, ${ }^{123,124}$ and had significant oral CS-sparing effects. ${ }^{125}$ In a Phase IIA trial in patients with COPD with sputum eosinophilia ( $\geq 3 \%$ ), benralizumab treatment did not significantly reduce the annual rate of moderate or severe acute exacerbations. However, significant improvements in $\mathrm{FEV}_{1}$ were observed 
Table 3 Recent and ongoing trials for monoclonal antibody treatments targeting eosinophils in COPD

\begin{tabular}{|c|c|c|c|c|}
\hline Agent; target & Study & Regimen & $\begin{array}{l}\text { Primary end } \\
\text { point }\end{array}$ & Findings if available \\
\hline \multirow[t]{3}{*}{$\begin{array}{l}\text { Mepolizumab; } \\
\text { IL5 }^{105,106,111-1 / 3}\end{array}$} & $\begin{array}{l}\text { NCT02I0596I (METREO): Phase III; } \\
\text { efficacy and safety of mepolizumab as } \\
\text { an add-on treatment in COPD }{ }^{105} \\
\text { Objective: evaluate efficacy and } \\
\text { safety in severe COPD with blood } \\
\text { eosinophil counts of } \geq 150 \text { cells } / \mu \mathrm{L} \\
\text { and exacerbations despite regular use } \\
\text { of maximal tolerated therapy }\end{array}$ & $\begin{array}{l}100 \mathrm{mg} \text { or } 300 \mathrm{mg} \text {; } \\
\mathrm{SC} \text {; Q4W (13 injections } \\
\text { during a } 52 \text { week } \\
\text { period) plus standard of } \\
\text { care COPD medication, } \\
\text { vs placebo plus standard } \\
\text { of care }\end{array}$ & $\begin{array}{l}\text { Frequency of } \\
\text { moderate/severe } \\
\text { exacerbations }\end{array}$ & $\begin{array}{l}\text { Study completed; mepolizumab } \\
\text { resulted in reduction in frequency } \\
\text { of moderate and severe } \\
\text { exacerbations compared to } \\
\text { placebo, but the difference was } \\
\text { not statistically significant }{ }^{13}\end{array}$ \\
\hline & $\begin{array}{l}\text { NCT0I463644: Phase III; mepolizumab } \\
\text { in COPD with eosinophilic } \\
\text { bronchitis }^{137} \\
\text { Objective: determine if mepolizumab } \\
\text { decreases sputum eosinophils in } \\
\text { patients with fixed airflow obstruction } \\
\text { (COPD) and eosinophilic bronchitis }\end{array}$ & $\begin{array}{l}750 \text { mg; IV; once per } \\
\text { month, vs placebo }\end{array}$ & $\begin{array}{l}\text { Percentage } \\
\text { decrease } \\
\text { in sputum } \\
\text { eosinophils from } \\
\text { baseline }\end{array}$ & $\begin{array}{l}\text { Study is completed. Although } \\
\text { mepolizumab significantly } \\
\text { reduced sputum eosinophils and } \\
\text { blood eosinophils compared } \\
\text { with placebo, it did not improve } \\
\text { lung function or reduce } \\
\text { exacerbation rates in COPD with } \\
\text { eosinophilia"' }\end{array}$ \\
\hline & $\begin{array}{l}\text { NCT02 I05948 (METREX): } \\
\text { Phase III; study to evaluate efficacy and } \\
\text { safety of mepolizumab for frequently } \\
\text { exacerbating COPD patients } 106 \\
\text { Objective: evaluate efficacy and safety } \\
\text { in patients with COPD at high risk of } \\
\text { exacerbations despite use of optimized } \\
\text { standard-of-care therapy; patients } \\
\text { stratified on basis of blood eosinophil } \\
\text { count } \geq 150 \text { cells/ } \mu \mathrm{L} \text { at screening or } \\
\geq 300 \text { cells/ } \mu \mathrm{L} \text { in the prior year versus } \\
\text { noneosinophilic phenotype }\end{array}$ & $\begin{array}{l}\text { I00 mg; SC; Q4W, } \\
\text { vs placebo }\end{array}$ & $\begin{array}{l}\text { Frequency of } \\
\text { moderate/severe } \\
\text { exacerbations }\end{array}$ & $\begin{array}{l}\text { Study completed }{ }^{106} ; \text { mepolizumab } \\
\text { resulted in significant reduction } \\
\text { in frequency of moderate and } \\
\text { severe exacerbations compared to } \\
\text { placebo in the eosinophilic group } \\
(1.40 \text { vs } 1.71 \text { per year, rate ratio } \\
0.82 ; 95 \% \mathrm{Cl} 0.68-0.98 \text {; adjusted } \\
P=0.04)^{113}\end{array}$ \\
\hline Reslizumab; IL5 ${ }^{\prime 10}$ & No documented studies in COPD & & & \\
\hline \multirow[t]{3}{*}{$\begin{array}{l}\text { Benralizumab; IL5 } \\
\text { receptor- } \alpha\end{array}$} & $\begin{array}{l}\text { NCT0I227278: Phase IIA; a study to } \\
\text { evaluate the effectiveness of MEDI563 } \\
\text { in subjects with chronic COPD } \\
\text { Objective: evaluate the effect of } \\
\text { benralizumab in adults with } \\
\text { moderate-severe COPD }\end{array}$ & $\begin{array}{l}\text { I00 mg; Q4W } \times 3 \\
\text { doses, then } \mathrm{Q} 8 \mathrm{~W} \times 5 \\
\text { doses, vs placebo }\end{array}$ & $\begin{array}{l}\text { Annual rate of } \\
\text { moderate or } \\
\text { severe acute } \\
\text { exacerbation of } \\
\text { COPD }\end{array}$ & $\begin{array}{l}\text { Study is completed. Demonstrated } \\
\text { rapid, nearly complete, } \\
\text { reversible depletion of sputum } \\
\text { and blood eosinophils; also } \\
\text { identified subgroup of patients } \\
\text { ( } \geq 200 \text { or } \geq 300 \text { eosinophils/ } / \mathrm{L}) \\
\text { who showed greater clinical } \\
\text { benefits from benralizumab } \\
\text { treatment, though treatment } \\
\text { effects did not reach statistical } \\
\text { significance }^{54}\end{array}$ \\
\hline & $\begin{array}{l}\text { TERRANOVA (NCT02I55660): } \\
\text { Phase III; efficacy and safety of } \\
\text { benralizumab in moderate-very severe } \\
\text { COPD with exacerbation history }{ }^{107} \\
\text { Objective: determine if benralizumab } \\
\text { reduces COPD exacerbation rates } \\
\text { in symptomatic patients receiving } \\
\text { standard care }\end{array}$ & $\begin{array}{l}\text { Dosage not given; SC; } \\
\text { schedule not given }\end{array}$ & $\begin{array}{l}\text { Annual COPD- } \\
\text { exacerbation rate }\end{array}$ & $\begin{array}{l}\text { Study ongoing, but not currently } \\
\text { recruiting participants; estimated } \\
\text { primary completion April } 2018\end{array}$ \\
\hline & $\begin{array}{l}\text { GALATHEA (NCT02I389I6): } \\
\text { Phase III; benralizumab efficacy in } \\
\text { moderate-very severe COPD with } \\
\text { exacerbation history } \\
\text { Objective: determine if benralizumab } \\
\text { reduces COPD-exacerbation rates } \\
\text { in symptomatic patients receiving } \\
\text { standard care }\end{array}$ & $\begin{array}{l}\text { Dose not given; SC; } \\
\text { schedule not given }\end{array}$ & $\begin{array}{l}\text { Annual COPD- } \\
\text { exacerbation rate }\end{array}$ & $\begin{array}{l}\text { Study ongoing, but not currently } \\
\text { recruiting participants; estimated } \\
\text { primary completion April } 2018\end{array}$ \\
\hline
\end{tabular}


Table 3 (Continued)

\begin{tabular}{|l|l|l|l|l|}
\hline Agent; target & Study & Regimen & $\begin{array}{l}\text { Primary end } \\
\text { point }\end{array}$ & Findings if available \\
\hline Lebrikizumab; ILI3 & $\begin{array}{l}\text { VALETA (NCT02546700): Phase 2; } \\
\text { study to evaluate safety and efficacy of } \\
\text { lebrikizumab in patients with COPD } \\
\text { Objective: assess safety, efficacy, and } \\
\text { patient-reported outcome measures } \\
\text { for patients with COPD with a history } \\
\text { of exacerbations and are treated with } \\
\text { ICS and at least one inhaled long-acting } \\
\text { bronchodilator }\end{array}$ & $\begin{array}{l}\text { I25 mg; SC; Q4W, } \\
\text { vs placebo }\end{array}$ & $\begin{array}{l}\text { Absolute change } \\
\text { from baseline in } \\
\text { prebronchodilator } \\
\text { FEV, at week I2 }\end{array}$ & $\begin{array}{l}\text { Study completed, but results not } \\
\text { yet available }\end{array}$ \\
\hline Tralokinumab; ILI3 $3^{130}$ & No documented studies in COPD & & & \\
\hline $\begin{array}{l}\text { Dupilumab; IL4 } \\
\text { receptor }{ }^{131}\end{array}$ & \begin{tabular}{l} 
No documented studies in COPD \\
\hline
\end{tabular}
\end{tabular}

Abbreviations: $\mathrm{FEV}_{1}$, forced expiratory volume in I second; IV, intravenous; Q4W, every 4 weeks; Q8W, every 8 weeks; SC, subcutaneous.

in the benralizumab group, and the results of prespecified subgroup analyses by baseline blood eosinophil count with benralizumab versus placebo supported further examination of benralizumab in patients with COPD. ${ }^{54}$ Ongoing Phase III trials evaluating benralizumab in COPD are described in Table 3.

Although IL13 has a more limited role in its scope of effects on eosinophils than IL5, it is a major factor mediating eosinophil recruitment to the lungs. ${ }^{126,127}$ Subcutaneous administration of the anti-IL13 monoclonal antibody lebrikizumab significantly increased mean $\mathrm{FEV}_{1}$ in asthma patients with high periostin blood concentrations versus placebo in a Phase II study. ${ }^{128}$ However, inconsistent results of lebrikizumab were seen in two recent Phase III studies evaluating its effects on asthma exacerbations (primary end point) in patients with elevated blood biomarkers ( $\geq 50 \mathrm{ng} / \mathrm{mL}$ periostin or $\geq 300$ eosinophils $/ \mu \mathrm{L}$ ), with one study (LAVOLTA I) yielding significant reductions in exacerbations and the other (LAVOLTA II) nonsignificant reductions. ${ }^{129}$ A Phase II trial of lebrikizumab has been completed in patients with COPD (Table 3). ${ }^{109}$ The anti-IL13 antibody tralokinumab (300 mg subcutaneously every 2 weeks [Q2W] to week 50 or Q2W to week 12 followed by Q4W to week 48) was investigated in a Phase IIB study (NCT01402986) in patients with severe uncontrolled asthma. ${ }^{130}$ Significant improvements in $\mathrm{FEV}_{1}$ were observed with the Q2W regimen versus placebo, and post hoc analyses suggested possible benefits of tralokinumab treatment in a defined patient subpopulation (including those with elevated serum dipeptidyl peptidase 4 and/or periostin concentrations). ${ }^{130}$ The potential utility of other antieosinophil targets for treatment of COPD (eg, antiIL4-receptor monoclonal antibody [dupilumab] ${ }^{131}$ CRTH2 antagonists [OC000459, ${ }^{132-135}$ fevipiprant ${ }^{136}$ ]) are yet to be determined, as these agents are not currently being evaluated in COPD.

\section{Conclusion}

Eosinophils are mediators of inflammation in many patients with COPD. Although a widely accepted threshold to define eosinophilic inflammation in the context of COPD has not been firmly established, elevated eosinophil counts have been associated with reduced lung function and increased risk of exacerbations in patients with COPD. Moreover, a reduction in eosinophilic inflammation is associated with reduced exacerbation frequency. Patients with COPD who have evidence of eosinophilic inflammation generally respond better to ICS treatment. Increased eosinophil counts in the blood may be an acceptable surrogate for airway eosinophilia and may serve as a readily accessible biomarker for ICS-treatment response in COPD. Emerging therapies targeting eosinophil chemotactic and survival factors, such as monoclonal antibodies targeting the IL5 ligand, the IL5 receptor, IL4 receptor, and the IL13 ligand, have been studied in asthma, and some are beginning to be studied in $\mathrm{COPD}$, where they may prove to be effective treatments.

\section{Acknowledgments}

We thank Beverly E Barton, PhD, Devin S Gary, PhD, and Stella Chow, PhD of Scientific Connexions, an Ashfield company, part of UDG Healthcare PLC (Lyndhurst, NJ, USA), and Courtney St Amour, PhD, of MedErgy HealthGroup Inc (Yardley, PA, USA) for medical writing support funded by AstraZeneca LP (Wilmington, DE, USA).

\section{Author contributions}

Both authors contributed to the development and critical revision of this manuscript, approved the final version to be 
published, and agree to be accountable for all aspects of the information contained in this review.

\section{Disclosure}

DPT has served on advisory boards for AstraZeneca, Novartis, and Sunovion, as a speaker for Boehringer-Ingelheim, and as a consultant for Theravance/Innoviva. MEW has served as a consultant for Ambit Bioscience, AstraZeneca, BoehringerIngelheim, BSCI, Genentech, Gilacure, GlaxoSmithKline, Meda, Mylan, Neurotronic, Novartis, Regeneron, Sanofi, Sunovion, Teva, Theravance, Tunitas, and Vectura, received research funding from Sanofi, served on an advisory board for Teva, was a DSMB member for Sentien, and received honoraria from BSCI. The authors report no other conflicts of interest in this work.

\section{References}

1. Global Initiative for Chronic Obstructive Lung Disease. Global Strategy for the Diagnosis, Management, and Prevention of COPD. Bethesda (MD): GOLD; 2017. Available from: http://goldcopd.org/gold-2017global-strategy-diagnosis-management-prevention-copd/. Accessed December 14, 2017.

2. Kim V, Rogers TJ, Criner GJ. New concepts in the pathobiology of chronic obstructive pulmonary disease. Proc Am Thorac Soc. 2008;5(4): 478-485.

3. Saha S, Brightling CE. Eosinophilic airway inflammation in COPD. Int J Chron Obstruct Pulmon Dis. 2006;1(1):39-47.

4. Cukic V, Lovre V, Dragisic D, Ustamujic A. Asthma and chronic obstructive pulmonary disease (COPD): differences and similarities. Mater Sociomed. 2012;24(2):100-105.

5. Eltboli O, Bafadhel M, Hollins F, et al. COPD exacerbation severity and frequency is associated with impaired macrophage efferocytosis of eosinophils. BMC Pulm Med. 2014;14:112.

6. Pizzichini E, Pizzichini MM, Gibson P, et al. Sputum eosinophilia predicts benefit from prednisone in smokers with chronic obstructive bronchitis. Am J Respir Crit Care Med. 1998;158(5 Pt 1):1511-1517.

7. Leigh R, Pizzichini MM, Morris MM, Maltais F, Hargreave FE, Pizzichini E. Stable COPD: predicting benefit from high-dose inhaled corticosteroid treatment. Eur Respir J. 2006;27(5):964-971.

8. Singh D, Kolsum U, Brightling CE, Locantore N, Agusti A, Tal-Singer R. Eosinophilic inflammation in COPD: prevalence and clinical characteristics. Eur Respir J. 2014;44(6):1697-1700.

9. Pascoe S, Locantore N, Dransfield MT, Barnes NC, Pavord ID. Blood eosinophil counts, exacerbations, and response to the addition of inhaled fluticasone furoate to vilanterol in patients with chronic obstructive pulmonary disease: a secondary analysis of data from two parallel randomised controlled trials. Lancet Respir Med. 2015;3(6):435-442.

10. Bafadhel M, McKenna S, Terry S, et al. Acute exacerbations of chronic obstructive pulmonary disease: identification of biologic clusters and their biomarkers. Am J Respir Crit Care Med. 2011;184(6):662-671.

11. Jacobsen EA, Helmers RA, Lee JJ, Lee NA. The expanding role(s) of eosinophils in health and disease. Blood. 2012;120(19):3882-3890.

12. George L, Brightling CE. Eosinophilic airway inflammation: role in asthma and chronic obstructive pulmonary disease. Ther Adv Chronic Dis. 2016;7(1):34-51.

13. Hogan SP, Rosenberg HF, Moqbel R, et al. Eosinophils: biological properties and role in health and disease. Clin Exp Allergy. 2008;38(5): 709-750.

14. Davoine F, Lacy P. Eosinophil cytokines, chemokines, and growth factors: emerging roles in immunity. Front Immunol. 2014;5:570.
15. Luijk B, Lindemans CA, Kanters D, et al. Gradual increase in priming of human eosinophils during extravasation from peripheral blood to the airways in response to allergen challenge. J Allergy Clin Immunol. 2005;115(5):997-1003.

16. Molfino NA, Gossage D, Kolbeck R, Parker JM, Geba GP. Molecular and clinical rationale for therapeutic targeting of interleukin-5 and its receptor. Clin Exp Allergy. 2012;42(5):712-737.

17. Conroy DM, Williams TJ. Eotaxin and the attraction of eosinophils to the asthmatic lung. Respir Res. 2001;2(3):150-156.

18. Smit JJ, Lukacs NW. A closer look at chemokines and their role in asthmatic responses. Eur J Pharmacol. 2006;533(1-3):277-288.

19. Moqbel R, Levi-Schaffer F, Kay AB. Cytokine generation by eosinophils. J Allergy Clin Immunol. 1994;94(6 Pt 2):1183-1188.

20. Kita H. The eosinophil: a cytokine-producing cell? J Allergy Clin Immunol. 1996;97(4):889-892.

21. Ziegler SF, Roan F, Bell BD, Stoklasek TA, Kitajima M, Han H. The biology of thymic stromal lymphopoietin (TSLP). Adv Pharmacol. 2013;66:129-155.

22. Redhu NS, Gounni AS. Function and mechanisms of TSLP/TSLPR complex in asthma and COPD. Clin Exp Allergy. 2012;42(7):994-1005.

23. Rutgers SR, Timens W, Kaufmann HF, van der Mark TW, Koëter GH, Postma DS. Comparison of induced sputum with bronchial wash, bronchoalveolar lavage and bronchial biopsies in COPD. Eur Respir J. 2000;15(1):109-115.

24. Meyer KC, Raghu G, Baughman RP, et al. An official American Thoracic Society clinical practice guideline: the clinical utility of bronchoalveolar lavage cellular analysis in interstitial lung disease. Am J Respir Crit Care Med. 2012;185(9):1004-1014.

25. Brightling CE, Bradding P, Symon FA, Holgate ST, Wardlaw AJ, Pavord ID. Mast-cell infiltration of airway smooth muscle in asthma. N Engl J Med. 2002;346(22):1699-1705.

26. Grootendorst DC, Sont JK, Willems LN, et al. Comparison of inflammatory cell counts in asthma: induced sputum vs bronchoalveolar lavage and bronchial biopsies. Clin Exp Allergy. 1997;27(7):769-779.

27. Duh SH, Cook JD. Laboratory reference range values. 2005. Available from: www.stedmansonline.com/webFiles/Dict-Stedmans28/APP17. pdf. Accessed December 6, 2017.

28. Medical Council of Canada. Clinical laboratory tests - normal values. Available from: http://mcc.ca/objectives/normal-values. Accessed December 6, 2017.

29. Medline Plus. Blood differential test. Available from: https://medlineplus.gov/ency/article/003657.htm. Accessed December 6, 2017.

30. Winkel P, Statland BE, Saunders AM, Osborn H, Kupperman H. Within-day physiologic variation of leukocyte types in healthy subjects as assayed by two automated leukocyte differential analyzers. Am J Clin Pathol. 1981;75(5):693-700.

31. Zacharski LR, Elveback LR, Kinman JW. Leukocyte counts in healthy adults. Am J Clin Pathol. 1971;56(2):148-150.

32. Young B, Lowe JO, Stevens A, Heath JW. Wheater's Functional Histology. 6th ed. Philadelphia: Churchill Livingstone; 2014.

33. Vedel-Krogh S, Nielsen SF, Lange P, Vestbo J, Nordestgaard BG. Blood eosinophils and exacerbations in chronic obstructive pulmonary disease: the Copenhagen general population study. Am J Respir Crit Care Med. 2016;193(9):965-974.

34. Chisale MR, Kumwenda P, Ngwira M, M'Baya B, Chosamata BI, Mwapasa V. A pilot study to determine the normal haematological indices for young Malawian adults in Blantyre, Malawi. Malawi MedJ. 2015;27(3):96-100.

35. Wang B, Yan L, Yao Z, Roskos LK. Population pharmacokinetics and pharmacodynamics of benralizumab in healthy volunteers and patients with asthma. CPT Pharmacometrics Syst Pharmacol. 2017;6(4):249-257.

36. Balbi B, Pignatti P, Corradi M, et al. Bronchoalveolar lavage, sputum and exhaled clinically relevant inflammatory markers: values in healthy adults. Eur Respir J. 2007;30(4):769-781.

37. Davidson WJ, The S, Leigh R. Establishing a normal range for induced sputum cell counts in western Canada. Can Respir J. 2013;20(6): 424-425. 
38. Negewo NA, McDonald VM, Baines KJ, et al. Peripheral blood eosinophils: a surrogate marker for airway eosinophilia in stable COPD. Int J Chron Obstruct Pulmon Dis. 2016;11:1495-1504.

39. Kreindler JL, Watkins ML, Lettis S, Tal-Singer R, Locantore N. Effect of inhaled corticosteroids on blood eosinophil count in steroid-naïve patients with COPD. BMJ Open Respir Res. 2016;3(1):e000151.

40. Brightling CE, Monteiro W, Ward R, et al. Sputum eosinophilia and shortterm response to prednisolone in chronic obstructive pulmonary disease: a randomised controlled trial. Lancet. 2000;356(9240):1480-1485.

41. Roy K, Smith J, Kolsum U, Borrill Z, Vestbo J, Singh D. COPD phenotype description using principal components analysis. Respir Res. 2009; 10:41.

42. Bafadhel M, McKenna S, Terry S, et al. Blood eosinophils to direct corticosteroid treatment of exacerbations of chronic obstructive pulmonary disease: a randomized placebo-controlled trial. Am J Respir Crit Care Med. 2012;186(1):48-55.

43. Lacoste JY, Bousquet J, Chanez P, et al. Eosinophilic and neutrophilic inflammation in asthma, chronic bronchitis, and chronic obstructive pulmonary disease. J Allergy Clin Immunol. 1993;92(4):537-548.

44. Amini M, Bashirova D, Prins BP, et al. Eosinophil count is a common factor for complex metabolic and pulmonary traits and diseases: the LifeLines Cohort Study. PLoS One. 2016;11(12):e0168480.

45. Sennels HP, Jørgensen HL, Hansen AL, Goetze JP, Fahrenkrug J. Diurnal variation of hematology parameters in healthy young males: the Bispebjerg study of diurnal variations. Scand J Clin Lab Invest. 2011;71(7):532-541.

46. Spector SL, Tan RA. Is a single blood eosinophil count a reliable marker for “eosinophilic asthma"? J Asthma. 2012;49(8):807-810.

47. Basanta M, Ibrahim B, Dockry R, et al. Exhaled volatile organic compounds for phenotyping chronic obstructive pulmonary disease: a cross-sectional study. Respir Res. 2012;13:72.

48. Brightling CE, McKenna S, Hargadon B, et al. Sputum eosinophilia and the short term response to inhaled mometasone in chronic obstructive pulmonary disease. Thorax. 2005;60(3):193-198.

49. Pavord ID, Lettis S, Locantore N, et al. Blood eosinophils and inhaled corticosteroid/long-acting $\beta$-2 agonist efficacy in COPD. Thorax. 2016; 71(2):118-125.

50. Pavord ID, Lettis S, Anzueto A, Barnes N. Blood eosinophil count and pneumonia risk in patients with chronic obstructive pulmonary disease: a patient-level meta-analysis. Lancet Respir Med. 2016;4(9):731-741.

51. Ortega H, Katz L, Gunsoy N, Keene O, Yancey S. Blood eosinophil counts predict treatment response in patients with severe eosinophilic asthma. J Allergy Clin Immunol. 2015;136(3):825-826.

52. Schleich F, Brusselle G, Louis R, et al. Heterogeneity of phenotypes in severe asthmatics: the Belgian Severe Asthma Registry (BSAR). Respir Med. 2014;108(12):1723-1732.

53. Watz H, Tetzlaff K, Wouters EF, et al. Blood eosinophil count and exacerbations in severe chronic obstructive pulmonary disease after withdrawal of inhaled corticosteroids: a post-hoc analysis of the WISDOM trial. Lancet Respir Med. 2016;4(5):390-398.

54. Brightling CE, Bleecker ER, Panettieri RA, et al. Benralizumab for chronic obstructive pulmonary disease and sputum eosinophilia: a randomised, double-blind, placebo-controlled, phase 2A study. Lancet Respir Med. 2014;2(11):891-901.

55. Siddiqui SH, Guasconi A, Vestbo J, et al. Blood eosinophils: a biomarker of response to extrafine beclomethasone/formoterol in chronic obstructive pulmonary disease. Am J Respir Crit Care Med. 2015; 192(4):523-525

56. Wedzicha JA, Banerji D, Chapman KR, et al. Indacaterol-glycopyrronium versus salmeterol-fluticasone for COPD. $N$ Engl J Med. 2016;374(23):2222-2234.

57. Barnes N, Sharma R, Lettis S, Calvarley P. Blood eosinophils as a marker of response to inhaled corticosteroids in COPD. Eur Respir J. 2016;47:1299-1303.

58. de Groot JC, Storm H, Amelink M, et al. Clinical profile of patients with adult-onset eosinophilic asthma. ERJ Open Res. 2016;2(2): $00100-2015$.
59. Eltboli O, Mistry V, Barker B, Brightling CE. Relationship between blood and bronchial submucosal eosinophilia and reticular basement membrane thickening in chronic obstructive pulmonary disease. Respirology. 2015;20(4):667-670.

60. Hastie A, Alexis N, Doerschuck C. Blood eosinophils poorly correlate with sputum eosinophils, and have few associations with spirometry, clinical and quantitated computed tomography measures compared to sputum eosinophils in the SPIROMICS cohort. Am J Respir Crit Care Med. 2016;139 Suppl. Available from: http://www.atsjournals.org/doi/ abs/10.1164/ajrccm-conference.2016.193.1_MeetingAbstracts.A6168. Accessed December 12, 2017

61. Kolsum U, Damera G, Pham TH, et al. Pulmonary inflammation in patients with chronic obstructive pulmonary disease with higher blood eosinophil counts. J Allergy Clin Immunol. 2017;140(4):1181.e7-1184.e7.

62. Turato G, Semenzato U, Bazzan E, et al. Blood eosinophilia does not reflect tissue eosinophils nor worsen clinical outcomes in COPD. Am J Respir Crit Care Med. Epub 2017 Oct 16.

63. Ravin KA, Loy M. The eosinophil in infection. Clin Rev Allergy Immunol. 2016;50(2):214-227.

64. Oshagbemi OA, Burden AM, Braeken DCW, et al. Stability of blood eosinophils in patients with chronic obstructive pulmonary disease and in control subjects, and the impact of sex, age, smoking, and baseline counts. Am J Respir Crit Care Med. 2017;195(10):1402-1404.

65. Moermans C, Bonnet C, Willems E, et al. Sputum cytokine levels in patients undergoing hematopoietic SCT and comparison with healthy subjects and COPD: a pilot study. Bone Marrow Transplant. 2014; 49(11):1382-1388.

66. Balzano G, Stefanelli F, Iorio C, et al. Eosinophilic inflammation in stable chronic obstructive pulmonary disease: relationship with neutrophils and airway function. Am J Respir Crit Care Med. 1999; 160(5 Pt 1):1486-1492.

67. Moermans C, Heinen V, Nguyen M, et al. Local and systemic cellular inflammation and cytokine release in chronic obstructive pulmonary disease. Cytokine. 2011;56(2):298-304.

68. Kim VL, Coombs NA, Staples KJ, et al. Impact and associations of eosinophilic inflammation in COPD: analysis of the AERIS cohort. Eur Respir J. 2017;50(4).

69. University of North Carolina. Study of COPD subgroups and biomarkers (SPIROMICS). Available from: https://clinicaltrials.gov/ ct2/show/NCT01969344. NLM identifier: NCT01969344. Accessed December 12, 2017.

70. Martinez CH, Li SX, Hirzel AJ, et al. Alveolar eosinophilia in current smokers with chronic obstructive pulmonary disease in the SPIROMICS cohort. J Allergy Clin Immunol. Epub 2017 Sep 12.

71. Brigham and Women's Hospital. Examining the genetic factors that may cause chronic obstructive pulmonary disease (COPD) (COPDGene). Available from: https://clinicaltrials.gov/ct2/ show/NCT00608764. NLM identifier: NCT00608764. Accessed December 12, 2017.

72. AstraZeneca. Observational study of obstructive lung disease (NOVELTY). Available from: https:/clinicaltrials.gov/ct2/show/NCT02760329. NLM identifier: NCT02760329. Accessed December 12, 2017.

73. Price D, Rigazio A, Postma D, et al. Blood eosinophilia and the number of exacerbations in COPD patients. Eur Respir J. 2014; 44 Suppl 58:4416.

74. Papi A, Bellettato CM, Braccioni F, et al. Infections and airway inflammation in chronic obstructive pulmonary disease severe exacerbations. Am J Respir Crit Care Med. 2006;173(10):1114-1121.

75. Fujimoto K, Yasuo M, Urushibata K, Hanaoka M, Koizumi T, Kubo K. Airway inflammation during stable and acutely exacerbated chronic obstructive pulmonary disease. Eur Respir J. 2005;25(4):640-646.

76. Prins HJ, Duijkers R, Lutter R, et al. Blood eosinophilia as a marker of early and late treatment failure in severe acute exacerbations of COPD. Respir Med. 2017;131:118-124

77. Cheng SL, Lin CH. Effectiveness using higher inhaled corticosteroid dosage in patients with COPD by different blood eosinophilic counts. Int J Chron Obstruct Pulmon Dis. 2016;11:2341-2348. 
78. Siva R, Green RH, Brightling CE, et al. Eosinophilic airway inflammation and exacerbations of COPD: a randomised controlled trial. Eur Respir J. 2007;29(5):906-913.

79. Kolsum U, Donaldson GC, Singh R, et al. Blood and sputum eosinophils in COPD: relationship with bacterial load. Respir Res. 2017;18(1):88.

80. Contoli M, Pauletti A, Rossi MR, et al. Long-term effects of inhaled corticosteroids on sputum bacterial and viral loads in COPD. Eur Respir J. 2017;50(4):1700451.

81. Lams BE, Sousa AR, Rees PJ, Lee TH. Subepithelial immunopathology of the large airways in smokers with and without chronic obstructive pulmonary disease. Eur Respir J. 2000;15(3):512-516.

82. Miller M, Ramsdell J, Friedman PJ, Cho JY, Renvall M, Broide DH. Computed tomographic scan-diagnosed chronic obstructive pulmonary disease-emphysema: eotaxin-1 is associated with bronchodilator response and extent of emphysema. J Allergy Clin Immunol. 2007; 120(5):1118-1125.

83. D'Armiento JM, Scharf SM, Roth MD, et al. Eosinophil and T cell markers predict functional decline in COPD patients. Respir Res. 2009; 10:113.

84. Janson C, Larsson K, Lisspers KH, et al. Pneumonia and pneumonia related mortality in patients with COPD treated with fixed combinations of inhaled corticosteroid and long acting $\beta_{2}$ agonist: observational matched cohort study (PATHOS). BMJ. 2013;346:f3306.

85. Kew KM, Seniukovich A. Inhaled steroids and risk of pneumonia for chronic obstructive pulmonary disease. Cochrane Database Syst Rev. 2014;(3):CD010115.

86. Morjaria JB, Rigby A, Morice AH. Inhaled corticosteroid use and the risk of pneumonia and COPD exacerbations in the UPLIFT study. Lung. 2017;195(3):281-288.

87. Singh S, Loke YK. Risk of pneumonia associated with long-term use of inhaled corticosteroids in chronic obstructive pulmonary disease: a critical review and update. Curr Opin Pulm Med. 2010;16(2):118-122.

88. Suissa S, Patenaude V, Lapi F, Ernst P. Inhaled corticosteroids in COPD and the risk of serious pneumonia. Thorax. 2013;68(11):1029-1036.

89. Wang CY, Lai CC, Yang WC, et al. The association between inhaled corticosteroid and pneumonia in COPD patients: the improvement of patients' life quality with COPD in Taiwan (IMPACT) study. Int $J$ Chron Obstruct Pulmon Dis. 2016;11:2775-2783.

90. Hinds DR, DiSantostefano RL, Le HV, Pascoe S. Identification of responders to inhaled corticosteroids in a chronic obstructive pulmonary disease population using cluster analysis. BMJ Open. 2016;6(6): e010099.

91. Roche N, Chapman KR, Vogelmeier CF, et al. Blood eosinophils and response to maintenance chronic obstructive pulmonary disease treatment: data from the FLAME trial. Am J Respir Crit Care Med. 2017; 195(9):1189-1197.

92. Postma DS, Rabe KF. The asthma-COPD overlap syndrome. $N$ Engl J Med. 2015;373(13):1241-1249.

93. Louis RE, Cataldo D, Buckley MG, et al. Evidence of mast-cell activation in a subset of patients with eosinophilic chronic obstructive pulmonary disease. Eur Respir J. 2002;20(2):325-331.

94. Soltani A, Ewe YP, Lim ZS, et al. Mast cells in COPD airways: relationship to bronchodilator responsiveness and angiogenesis. Eur Respir J. 2012;39(6):1361-1367.

95. Sin DD, Miravitlles M, Mannino DM, et al. What is asthma-COPD overlap syndrome? Towards a consensus definition from a round table discussion. Eur Respir J. 2016;48(3):664-673.

96. Global Initiative for Asthma (GINA). Global Strategy for Asthma Management and Prevention. 2017. Available from: http://ginasthma. org/2017-gina-report-global-strategy-for-asthma-management-andprevention/. Accessed December 13, 2017.

97. Soler-Cataluña JJ, Cosío B, Izquierdo JL, et al. Consensus document on the overlap phenotype COPD-asthma in COPD. Arch Bronconeumol. 2012;48(9):331-337.
98. Koblizek V, Chlumsky J, Zindr V, et al. Chronic obstructive pulmonary disease: official diagnosis and treatment guidelines of the Czech Pneumological and Phthisiological Society; a novel phenotypic approach to COPD with patient-oriented care. Biomed Pap Med Fac Univ Palacky Olomouc Czech Repub. 2013;157(2):189-201.

99. Cosío BG, Soriano JB, Lopez-Campos JL, et al. Defining the asthmaCOPD overlap syndrome in a COPD cohort. Chest. 2016;149(1): 45-52.

100. Cosío BG, de Llano LP, Viña AL, et al. Th-2 signature in chronic airway diseases: towards the extinction of asthma-COPD overlap syndrome? Eur Respir J. 2017;49(5):1602397.

101. Miravitlles M, Soler-Cataluña JJ, Calle M, et al. Spanish guidelines for management of chronic obstructive pulmonary disease (GesEPOC) 2017: pharmacological treatment of stable phase. Arch Bronconeumol. 2017;53(6):324-335.

102. Wedzicha JA, Calverley PM, Seemungal TA, et al. The prevention of chronic obstructive pulmonary disease exacerbations by salmeterol/ fluticasone propionate or tiotropium bromide. Am J Respir Crit Care Med. 2008;177(1):19-26.

103. Hollis S, Jorup C, Lythgoe D, Martensson G, Regnell P, Eckerwall G. Risk of pneumonia with budesonide-containing treatments in COPD: an individual patient-level pooled analysis of interventional studies. Int J Chron Obstruct Pulmon Dis. 2017;12:1071-1084.

104. Sin DD, Tashkin D, Zhang $X$, et al. Budesonide and the risk of pneumonia: a meta-analysis of individual patient data. Lancet. 2009;374(9691):712-719.

105. GlaxoSmithKline. Efficacy and safety of mepolizumab as an add-on treatment in COPD. Available from: https://clinicaltrials.gov/ct2/ show/NCT02105961. NLM identifier: NCT02105961. Accessed December 14, 2017.

106. GlaxoSmithKline. Study to evaluate efficacy and safety of mepolizumab for frequently exacerbating COPD patients. Available from: https:/clinicaltrials.gov/ct2/show/NCT02105948. NLM identifier: NCT02105948. Accessed December 14, 2017.

107. AstraZeneca. Efficacy and safety of benralizumab in patients with moderate to very severe COPD with exacerbation history (TERRANOVA). Available from: https://clinicaltrials.gov/ct2/show/NCT02155660. NLM identifier: NCT02155660. Accessed December 14, 2017.

108. AstraZeneca. Benralizumab efficacy in moderate to very severe COPD with exacerbation history (GALATHEA). Available from: https:/clinicaltrials.gov/ct2/show/NCT02138916. NLM identifier: NCT02138916. Accessed December 14, 2017.

109. Hoffmann-La Roche. A study to evaluate safety and efficacy of lebrikizumab in patients with chronic obstructive pulmonary disease. Available from: https:/clinicaltrials.gov/ct2/show/NCT02546700. NLM identifier: NCT02546700. Accessed December 14, 2017.

110. Corren J, Weinstein S, Janka L, Zangrilli J, Garin M. Phase 3 study of reslizumab in patients with poorly controlled asthma: effects across a broad range of eosinophil counts. Chest. 2016;150(4):799-810.

111. Dasgupta A, Kjarsgaard M, Capaldi D, et al. A pilot randomised clinical trial of mepolizumab in COPD with eosinophilic bronchitis. Eur Respir J. 2017;49(3):1602486.

112. GlaxoSmithKline. GSK announces headline phase III results of mepolizumab in patients with severe chronic obstructive pulmonary disease [press release]. London: GSK; 2017 [May 10]. Available from: https://www.gsk.com/en-gb/media/press-releases/gsk-announcesheadline-phase-iii-results-of-mepolizumab-in-patients-with-severechronic-obstructive-pulmonary-disease. Accessed December 14, 2017.

113. Pavord ID, Chanez P, Criner GJ, et al. Mepolizumab for eosinophilic chronic obstructive pulmonary disease. N Engl J Med. 2017; 377(17):1613-1629.

114. Keating GM. Mepolizumab: First Global Approval. Drugs. 2015; 75(18):2163-2169. 
115. NUCALA [package insert]. Research Triangle Park, NC: GlaxoSmithKline; December 2017. Available from: https://www.gsksource. com/pharma/content/dam/GlaxoSmithKline/US/en/Prescribing_Information/Nucala/pdf/NUCALA-PI-PIL.pdf. Accessed December 14, 2017.

116. Bel EH, Wenzel SE, Thompson PJ, et al. Oral glucocorticoid-sparing effect of mepolizumab in eosinophilic asthma. N Engl J Med. 2014; 371(13):1189-1197.

117. Ortega HG, Liu MC, Pavord ID, et al. Mepolizumab treatment in patients with severe eosinophilic asthma. N Engl J Med. 2014; 371(13):1198-1207.

118. Pavord ID, Korn S, Howarth P, et al. Mepolizumab for severe eosinophilic asthma (DREAM): a multicentre, double-blind, placebocontrolled trial. Lancet. 2012;380(9842):651-659.

119. Nair P, Dasgupta A, Kjarsgaard M, et al. Mepolizumab in COPD with eosinophilic bronchitis: a randomized clinical trial. J Allergy Clin Immunol. 2016;137(2):AS392.

120. CINQAIR ${ }^{\circledR}$ [package insert]. Frazer, PA: Teva Respiratory, LLC; 2016.

121. Castro M, Mathur S, Hargreave F, et al. Reslizumab for poorly controlled, eosinophilic asthma: a randomized, placebo-controlled study. Am J Respir Crit Care Med. 2011;184(10):1125-1132.

122. Castro M, Zangrilli J, Wechsler ME, et al. Reslizumab for inadequately controlled asthma with elevated blood eosinophil counts: results from two multicentre, parallel, double-blind, randomised, placebo-controlled, phase 3 trials. Lancet Respir Med. 2015;3(5): 355-366

123. FitzGerald JM, Bleecker ER, Nair P, et al. Benralizumab, an antiinterleukin-5 receptor $\alpha$ monoclonal antibody, as add-on treatment for patients with severe, uncontrolled, eosinophilic asthma (CALIMA) a randomised, double-blind, placebo-controlled phase 3 trial. Lancet. 2016;388(10056):2128-2141.

124. Bleecker ER, FitzGerald JM, Chanez P, et al. Efficacy and safety of benralizumab for patients with severe asthma uncontrolled with high-dosage inhaled corticosteroids and long-acting $\beta_{2}$-agonists (SIROCCO): a randomised, multicentre, placebo-controlled phase 3 trial. Lancet. 2016;388(10056):2115-2127.

125. Nair P, Wenzel S, Rabe KF, et al. Oral glucocorticoid-sparing effect of benralizumab in severe asthma. $N$ Engl J Med. 2017;376(25): 2448-2458

126. Fajt ML, Wenzel SE. Asthma phenotypes and the use of biologic medications in asthma and allergic disease: the next steps toward personalized care. J Allergy Clin Immunol. 2015;135(2):299-311.
127. Pope SM, Brandt EB, Mishra A, et al. IL-13 induces eosinophil recruitment into the lung by an IL-5- and eotaxin-dependent mechanism. J Allergy Clin Immunol. 2001;108(4):594-601.

128. Corren J, Lemanske RF, Hanania NA, et al. Lebrikizumab treatment in adults with asthma. $N$ Engl J Med. 2011;365(12):1088-1098.

129. Hanania NA, Korenblat P, Chapman KR, et al. Efficacy and safety of lebrikizumab in patients with uncontrolled asthma (LAVOLTA I and LAVOLTA II): replicate, phase 3, randomised, double-blind, placebo-controlled trials. Lancet Respir Med. 2016;4(10):781-796.

130. Brightling CE, Chanez P, Leigh R, et al. Efficacy and safety of tralokinumab in patients with severe uncontrolled asthma: a randomised, double-blind, placebo-controlled, phase 2B trial. Lancet Respir Med. 2015;3(9):692-701.

131. Wenzel S, Castro M, Corren J, et al. Dupilumab efficacy and safety in adults with uncontrolled persistent asthma despite use of mediumto-high-dose inhaled corticosteroids plus a long-acting $\beta_{2}$ agonist: a randomised double-blind placebo-controlled pivotal phase $2 \mathrm{~B}$ dose-ranging trial. Lancet. 2016;388(10039):31-44.

132. Barnes N, Pavord I, Chuchalin A, et al. A randomized, double-blind, placebo-controlled study of the CRTH2 antagonist OC000459 in moderate persistent asthma. Clin Exp Allergy. 2012;42(1):38-48.

133. Pettipher R, Hunter MG, Perkins CM, et al. Heightened response of eosinophilic asthmatic patients to the CRTH2 antagonist OC000459. Allergy. 2014;69(9):1223-1232.

134. Singh D, Cadden P, Hunter M, et al. Inhibition of the asthmatic allergen challenge response by the CRTH2 antagonist OC000459. Eur Respir J. 2013;41(1):46-52.

135. Straumann A, Hoesli S, Bussmann C, et al. Anti-eosinophil activity and clinical efficacy of the CRTH2 antagonist OC000459 in eosinophilic esophagitis. Allergy. 2013;68(3):375-385.

136. Gonem S, Berair R, Singapuri A, et al. Fevipiprant, a prostaglandin $\mathrm{D}_{2}$ receptor 2 antagonist, in patients with persistent eosinophilic asthma: a single-centre, randomised, double-blind, parallel-group, placebocontrolled trial. Lancet Respir Med. 2016;4(9):699-707.

137. McMaster University. Mepolizumab in chronic obstructive pulmonary diseases (COPD) with eosinophilic bronchitis. Available from: https:/clinicaltrials.gov/ct2/show/NCT01463644. NLM identifier: NCT01463644. Accessed December 14, 2017.

138. MedImmune LLC. A study to evaluate the effectiveness of MEDI563 in subjects with chronic obstructive pulmonary disease (COPD). Available from: https://clinicaltrials.gov/ct2/show/NCT01227278. NLM identifier: NCT01227278. Accessed December 14, 2017.
International Journal of COPD

\section{Publish your work in this journal}

The International Journal of COPD is an international, peer-reviewed journal of therapeutics and pharmacology focusing on concise rapid reporting of clinical studies and reviews in COPD. Special focus is given to the pathophysiological processes underlying the disease, intervention programs, patient focused education, and self management protocols.

\section{Dovepress}

This journal is indexed on PubMed Central, MedLine and CAS. The manuscript management system is completely online and includes a very quick and fair peer-review system, which is all easy to use. Visit http://www.dovepress.com/testimonials.php to read real quotes from published authors. 